\title{
ASO Author Reflections: Towards Patient-Tailored Management of Extremity Soft Tissue Sarcoma
}

\author{
I. Acem, $\mathrm{BS}^{1,2}$, M. A. J. van de Sande, $\mathrm{MD}, \mathrm{PhD}^{2}$, and C. Verhoef, $\mathrm{MD}, \mathrm{PhD}^{1}$ \\ ${ }^{1}$ Surgical Oncology and Gastrointestinal Surgery, Erasmus MC Cancer Institute, Rotterdam, Netherlands; ${ }^{2}$ Department of \\ Orthopedic surgery, Leiden University Medical Center, Leiden, Netherlands
}

\section{PAST}

A multimodality approach is often used in the management of high-grade soft tissue sarcoma of the extremity (eSTS). Limb-sparing surgery is the keystone of eSTS management, often accompanied with radiotherapy (RTX) and/or chemotherapy (CTX). The National Comprehensive Cancer Network (NCCN) and European Society for Medical Oncology (ESMO) guideline recommend RTX and CTX in selected groups of high-risk patients. ${ }^{1,2}$ However, the identification of these high-risk patients who benefit from perioperative treatment remains challenging. In the last decade, several prognostic tools and prognostic gene expression profiles have been developed to facilitate clinical decision-making for the indication of multimodality therapy. This marks a shift from a one-size-fits-all approach to a patient-tailored approach for the management and surveillance of eSTS.

\section{PRESENT}

Our cross-sectional study aimed to acquire insight into the variation of eSTS management across the world and to assess the importance of several clinicopathologic risk factors for the indication of multimodality therapy. ${ }^{3}$ Although studies have shown better patient outcomes when adhering to the clinical guidelines, this study showed remarkable variation in eSTS management and

(c) The Author(s) 2021

First Received: 2 April 2021

Accepted: 3 April 2021;

Published Online: 17 April 2021

I. Acem, BS

e-mail: i.acem@erasmusmc.nl surveillance across continents and physician specialties. Notably, a wide variation in attitude towards perioperative CTX was found across specialties. Mainly surgical and orthopedic oncologists did not feel there is sufficient evidence for the use of perioperative CTX in high-grade eSTS. Furthermore, Physicians were predominantly positive about the use of prognostic tools for the indication of multimodality therapy. In addition, this study showed a wide variation in the frequency of follow-up and follow-up modality, with a remarkable difference in preference for chest computed tomography (CT) scan versus chest X-ray across continents.

\section{FUTURE}

The optimal management of patients with eSTS remains an important field of research. Recent developments of prediction tools and advances in genomics and proteomics may allow for better patient selection for multimodality therapy. Because in recent years some retrospective studies have been performed to assess the use of these tools for the indication of multimodality therapy, further studies are needed to improve patient selection for the indication of multimodality therapy, with a special focus on perioperative CTX and new perioperative modalities. Also, the costeffectiveness of chest CT scan versus chest X-ray and the use of prognostic tools for patient-tailored follow-up regimen should be explored. Given the rarity and heterogeneity of eSTS, large collaborative efforts of international sarcoma centers are crucial to further improve patient-tailored management of eSTS.

OPEN ACCESS This article is licensed under a Creative Commons Attribution 4.0 International License, which permits use, sharing, adaptation, distribution and reproduction in any medium or format, as long as you give appropriate credit to the original author(s) and the source, provide a link to the Creative Commons licence, and indicate if changes were made. The images or other third party material in this 
article are included in the article's Creative Commons licence, unless indicated otherwise in a credit line to the material. If material is not included in the article's Creative Commons licence and your intended use is not permitted by statutory regulation or exceeds the permitted use, you will need to obtain permission directly from the copyright holder. To view a copy of this licence, visit http://creativecommons. org/licenses/by/4.0/.

\section{REFERENCES}

1. Von Mehren M, Randall RL, Benjamin RS, et al. Soft tissue sarcoma version 2.2018, NCCN clinical practice guidelines in oncology. Natl Compr Cancer Netw. 2018;16(5):536-63.
2. Casali PG, Abecassis N, Aro HT, et al. Soft tissue and visceral sarcomas: ESMO-EURACAN clinical practice guidelines for diagnosis treatment and follow-up. Ann Oncol. 2018;29(45):iv51-67.

3. Acem I, Smit MM, Verhoef C, et al. Management of Soft Tissue Sarcomas of extremities: Variation in treatment recommendations and surveillance according to specialty and continent. Ann Surg Oncol. 2021. https://doi.org/10.1245/s10434-021-09946-4.

Publisher's Note Springer Nature remains neutral with regard to jurisdictional claims in published maps and institutional affiliations. 